\title{
Possibilities of modification of risk factors for ventilator-associated pneumonia in cardiac surgery patients
}

\author{
Marta Wróblewskaํㅜ Agata Stępniak², Zbigniew Burnos², Marta Kania-Pudło ${ }^{3}$, Piotr Leszczyński ${ }^{1}$, \\ Piotr Hendzel ${ }^{2}$
}

${ }^{1}$ Laboratory of Nosocomial Infection Epidemiology, Chair and Department of Medical Microbiology, Medical University of Warsaw

${ }^{2}$ Department of Cardiac Surgery, Military Institute of Medicine, Warsaw

${ }^{3}$ Section of Hygiene and Epidemiology, Military Institute of Medicine, Warsaw

Kardiochirurgia i Torakochirurgia Polska 2013; 10 (4): 389-396

\begin{abstract}
Patients undergoing cardiac surgery require intensive care, the quality of which may significantly reduce the risk of postoperative complications in this patient group. Factors which decrease the risk of ventilator-associated pneumonia (VAP) include care provided to intubated and mechanically ventilated patients, maintenance of a semirecumbent position with elevation of the chest, enteral feeding, prevention of oropharyngeal colonization, and the use of sucralfate instead of $\mathrm{H} 2$ receptor antagonists in the prophylaxis of stress ulcers of the stomach. Similarly to other forms of nosocomial infections, the main element of VAP prophylaxis is proper hand hygiene of healthcare workers.
\end{abstract}

Key words: intensive care, cardiac surgery, ventilator-associated pneumonia.

\section{Introduction}

Patients undergoing cardiac surgery procedures are subject to enormous operative trauma, intensified further by the large size of the operated surface area. Early postoperative care in a cardiac surgery intensive care unit is aimed at minimizing the effects of trauma, broadly defined, which leads to weakening of the body's immune mechanisms and increases the risk of nosocomial infection.

Nosocomial infection is an infection that is acquired in a healthcare setting. Its definition is broad and includes not only patients, but also medical professionals and hospital domestic staff, as well as persons visiting the patient in the hospital. With regard to the patient, nosocomial infection is an infection which was not in its incubation period at the time of the patient's admission. It has been established arbitrarily

\section{Streszczenie}

Pacjent poddawany operacji kardiochirurgicznej wymaga intensywnej opieki, której jakość może w dużym stopniu zminimalizować ryzyko wystąpienia powikłań pooperacyjnych w tej grupie chorych. Do czynników mających wpływ na zmniejszenie ryzyka respiratorowego zapalenia płuc (VAP) należy opieka nad pacjentem zaintubowanym i wentylowanym mechanicznie, utrzymywanie pacjenta $w$ pozycji półleżącej $z$ uniesieniem klatki piersiowej, żywienie enteralne, przeciwdziałanie kolonizacji jamy ustno-gardłowej oraz stosowanie sukralfatu zamiast antagonistów receptorów $\mathrm{H} 2$ w celu zobojętnienia kwasu żołądkowego w profilaktyce owrzodzeń stresowych żołądka. Tak jak w przypadku innych postaci zakażeń szpitalnych, podstawowym elementem zapobiegania VAP jest właściwa higiena rąk personelu medycznego.

Słowa kluczowe: intensywna opieka, kardiochirurgia, respiratorowe zapalenie płuc.

that the symptoms of nosocomial infection appear at least 48 hours after the start of hospitalization, during the hospitalization, and within 10 days after the patient's discharge. In patients undergoing surgery, the latter period is extended to 30 days after the procedure, and in the case of biomaterial implantation, up to 1 year after the implantation.

\section{Definition of pneumonia}

Pneumonia is a pathological condition of the respiratory system involving the presence of inflammatory cells in the lung parenchyma and/or effusion in the pulmonary alveoli. These changes significantly inhibit gas exchange and impair breathing, leading to dyspnea and increased breathing frequency. Types and classification criteria of pneumonia occurring in hospitalized patients are presented in Table I.

Address for correspondence: Marta Wróblewska, Laboratory of Nosocomial Infection Epidemiology, Chair and Department of Medical Microbiology, Medical University of Warsaw, Chałubińskiego 5, 02-004 Warszawa, e-mail: martamwroblewska@gmail.com 
Table I. Classification of pneumonia in hospitalized patients (according to the 2005 ATS guidelines)

\begin{tabular}{ll} 
Type of pneumonia & Pneumonia classification criteria \\
hospital-acquired pneumonia (HAP) & symptoms appear $\geq 48 \mathrm{~h}$ after admission \\
\cline { 2 - 2 } & pneumonia was not incubating at the time of admission \\
\hline ventilator-associated pneumonia (VAP) & symptoms appear $\geq 48-72 \mathrm{~h}$ after endotracheal intubation* \\
\hline healthcare-associated pneumonia (HCAP) & $\begin{array}{l}\text { symptoms of pneumonia in a patient who was hospitalized in an acute care hospital for } \geq 2 \\
\text { days within } 90 \text { days of the infection }\end{array}$ \\
\cline { 2 - 2 } & \begin{tabular}{l} 
symptoms of pneumonia in a patient staying in a nursing home or long-term care facility \\
\cline { 2 - 2 } symptoms of pneumonia in a patient who received recent intravenous antibiotic therapy, \\
chemotherapy, or wound treatment within the past 30 days of the current infection
\end{tabular} \\
\cline { 2 - 2 } & $\begin{array}{l}\text { symptoms of pneumonia in a patient who was in a dialysis department or was admitted to } \\
\text { hospital for a period of time within the last } 30 \text { days }\end{array}$ \\
\hline
\end{tabular}

* Most authors assume the criterion of $\geq 48 \mathrm{~h}$ after endotracheal intubation.

Hospital-acquired pneumonia (HAP) is defined as pneumonia in which symptoms appear in a patient at least 48 hours after his/her admission to the hospital, and the existence of an inflammatory process in the lungs at the start of hospitalization is excluded [1].

According to the American Thoracic Society (ATS), pneumonia in patients undergoing mechanical ventilation is known as ventilator-associated pneumonia (VAP). This form of pneumonia appears more than 48-72 hours after the start of mechanical ventilation [1, 2]. Two types of HAP can be distinguished in this group, taking into account the time of symptom appearance [1]. Early-onset VAP appears within the first 4 days after intubation and is typically caused by the endogenous flora of the patient; late-onset VAP occurs $\geq 5$ days after intubation, and is caused by exogenous (hospital) bacteria [1]. Current ATS guidelines also distinguish healthcare-associated pneumonia (HCAP) [1]. The CDC definition of VAP diagnosis is presented in Table II [3].

\section{Modification of VAP risk factors}

Among many risk factors which favor the development of VAP, there are those that can be modified by altering procedures of providing healthcare to the patient. They include intubation and mechanical ventilation, body position, enteral nutrition, prevention of oropharyngeal colonization and pharmacological intervention aimed at neutralizing gastric acid. Modifying these factors is the fundamental measure that can be taken in order to prevent VAP. This issue was described in detail in the guidelines of the American Tho-

Table II. Criteria for VAP diagnosis in patients undergoing mechanical ventilation for $\geq 48$ hours (according to CDC)

\begin{tabular}{ll}
$\begin{array}{ll}\text { Radiological } \\
\text { criterion }\end{array}$ & Clinical criteria $(\geq 2)$ \\
the presence & fever $\geq 38.5^{\circ} \mathrm{C}$ or hypothermia $<36^{\circ} \mathrm{C}$ \\
\cline { 2 - 2 } $\begin{array}{l}\text { of new or } \\
\text { progressive } \\
\text { infiltrate of }\end{array}$ & leukocytosis $\geq 12 \times 10^{9} / 1$ \\
\cline { 2 - 2 } $\begin{array}{l}\text { lung paren- } \\
\text { chyma in } \\
\text { chest X-ray }\end{array}$ & $\begin{array}{l}\text { a drop in arterial partial pressure of oxygen }\left(\mathrm{PaO}_{2}\right) \\
\text { or a reduction in the fraction of inspired oxygen } \\
\left(\mathrm{FiO}_{2}\right) \text { by } \geq 15 \% \text { within the last } 48 \text { hours }\end{array}$ \\
\hline
\end{tabular}

racic Society (ATS) pertaining to the management of adult patients suffering from hospital-acquired pneumonia [1].

It should be stressed that maintaining hand hygiene and conducting regular training constitute important aspects of nosocomial infection prophylaxis [4-6]. An educational program should be offered especially to students and persons visiting the patient. The most recent scientific studies related to prophylaxis of hospital-acquired infections (including VAP) emphasize the significance of adhering to nursing staff employment norms. It is recommended that patients at high risk of lung infection be attended by nurses in a $1: 1$ ratio and if no such risk is present, two patients may be assigned to one nurse [5].

In VAP prophylaxis, the efficacy of the so-called ventilator bundle has been demonstrated; this grouping of practices includes the semirecumbent position of the mechanically ventilated patient, deep vein thromboembolism prophylaxis, prevention of stress-related gastric ulceration, daily "sedation vacations" and the assessment of the patient's readiness for extubation [2]. Morris et al. demonstrated that even employing a care bundle consisting of only four elements - head-ofbed elevation, local application of chlorhexidine gel in the oral cavity, daily sedation holds, and assessment of the patient's readiness for extubation - may reduce infection rates [7].

\section{Intubation and mechanical ventilation}

The use of non-invasive ventilation with a face mask is sometimes impossible and often ineffective. Therefore, in clinical practice it is often necessary to intubate the patient and employ mechanical ventilation, even though it is known that these procedures increase the risk of VAP by 6-21 times [1]. VAP prophylaxis requires careful selection of the intubation tube. Its size should be adjusted to the anatomical properties of the patient's upper airway, in order to ensure proper and easy clearance of the bronchial tree and provide the possibility of maintaining tube cuff pressure $>20 \mathrm{~cm} \mathrm{H} \mathrm{H}_{2} \mathrm{O}$, in order to prevent the transfer of bacteria from the oropharyngeal cavity to the lower respiratory tract [8]. The pressure inside the tube cuff should not, however, exceed $30 \mathrm{~cm} \mathrm{H}_{2} \mathrm{O}$, as this may impair the flow of blood and damage the tracheal mucous membrane [8]. 
Careful suctioning of secretion from the subglottic region of the intubated patient is an efficacious method of preventing $\operatorname{VAP}[4,9,10]$. Kollef et al. studied the influence of this procedure on VAP prophylaxis in cardiac surgery patients and observed that the time period before VAP onset was increased from 2.9 to 5.9 days [11]. A meta-analysis encompassing almost 2500 patients has recently demonstrated the efficiency of endotracheal tubes equipped with a system enabling the drainage of secretions from the subglottic region in providing VAP prophylaxis, shortening the ICU stay of the patient and reducing the number of days of assisted ventilation [12].

The route through which the tube is introduced is also significant. Oral intubation is recommended, as nasotracheal intubation is associated with the risk of sinusitis, which entails an increased presence of pathogens in the oropharyngeal cavity and an increased risk of VAP [4]. It should be remembered, however, that the endotracheal tube establishes a direct connection between the oropharyngeal cavity (colonized by bacterial flora) and the lower respiratory tract. For this reason, some authors believe that performing early tracheostomy (6-8 days after intubation), in comparison to late tracheostomy (14 days after intubation), may reduce the risk of VAP; however, this has not yet been unequivocally confirmed by clinical studies [13-16]. The intubation tube should be prevented from being accidentally removed, as reintubation further increases the risk of pneumonia [4, 14 17].

A mechanically ventilated patient is connected to the ventilator through a system of tubes providing gas flow. Studies have demonstrated that frequent exchange of these tubes does not significantly reduce the frequency of lower airway infection; therefore, they should be replaced only when they are soiled with the secretion from the patient's airway $[4,18]$. The colonization of the tube system by the so-called contaminated breath condensate may result in a respiratory system infection. Use of disposable tubes is currently recommended in clinical practice.

Moisteners and heat exchangers, used until recently in ventilators, may serve as reservoirs of bacteria. Currently, in order to eliminate this cause of VAP, single-use filters with heat and moisture exchangers are often employed; however, guidelines concerning their use are sometimes ambivalent [15]. The most recent guidelines, published in the USA in 2012, describe in detail the indications and contraindications for both the active and passive humidification of air exhaled by the ventilated patient [with heated humidifiers $(\mathrm{HHs})$ and heat and moisture exchangers (HMEs), respectively] [19]. It should be noted that no significant difference in VAP incidence has been demonstrated between the two methods, indicating, however, that HMEs should be used in the case of mechanical ventilation lasting $\leq 96$ hours and during the patient's transport, whereas HHs should be employed when the use of HMEs is contraindicated [19].

Shortening the duration of mechanical ventilation is also an efficacious method of preventing pneumonia. In order to achieve this, the patient should be weaned from ventilatory support by decreasing the dose of sedatives [5]. The intubation tube should be prevented from being accidentally removed, as reintubation further increases the risk of pneumonia $[4,14,17]$.

The evaluation of the patient's condition by means of proper scales, with regard to both analgesic efficacy and sedation depth, is key for achieving this goal. Without efficacious analgesic treatment, it is extremely difficult, if not impossible, to achieve adequate sedation. The purpose of pain monitoring is served by the appropriate scales: the Visual Analogue Scale (VAS), the Numeric Rating Scale (NRS), the Behavioral Pain Scale (BPS) and the Critical-Care Pain Observation Tool (CPOT). The VAS and NRS require the cooperation of the patient, while the BPS and CPOT may be used regardless of the level of patient cooperation. Several scales are also available for monitoring sedation: the Ramsay Scale, the Cook Scale, the Sedation Agitation Scale (SAS) and the increasingly popular Richmond Agitation Sedation Scale (RASS) [4, 5]. Healthcare professionals should strive to evaluate the condition of the patient every two hours, or even more often, in order to select adequate doses of analgesic and sedative agents [1]. An adequate protocol may also include the modification of medication by the nurse, depending on the level of analgesia and sedation.

In recent years, thanks to the "Pain-free hospital" campaign, the scheme of treating and monitoring pain has been popularized in Poland. The obligation to record documentation concerning the monitoring and treatment of pain was included in the regulation of the Health Ministry of December 21, 2010, pertaining to the types, extent, and methods of processing medical documentation. However, the monitoring of sedation depth is still not performed in many hospitals. The RASS scale is very useful for this purpose (Table III).

Another method of reducing VAP incidence among intubated patients may be the use of endotracheal tubes,

Table III. Richmond Agitation-Sedation Scale

\begin{tabular}{ll}
$\begin{array}{l}\text { Patient condition - } \\
\text { score and term }\end{array}$ & Patient condition - description \\
+4 combative & $\begin{array}{l}\text { overtly combative, violent, immediate danger } \\
\text { to staff }\end{array}$ \\
\hline+3 very agitated & $\begin{array}{l}\text { pulls or removes tube(s) or catheter(s); } \\
\text { aggressive }\end{array}$ \\
\hline+2 agitated & $\begin{array}{l}\text { frequent non-purposeful movement, fights } \\
\text { ventilator }\end{array}$ \\
\hline+1 restless & \begin{tabular}{l} 
anxious but movements not aggressive \\
\hline 0 alert and calm
\end{tabular} \\
\hline-1 drowsy & $\begin{array}{l}\text { not fully alert, but can be awakened (eye- } \\
\text {-opening/eye contact) by voice ( }>10 \text { seconds) }\end{array}$ \\
\hline-2 light sedation & $\begin{array}{l}\text { briefly awakens with eye contact to voice } \\
\text { (<10 seconds) }\end{array}$ \\
\hline-3 moderate & $\begin{array}{l}\text { movement or eye opening to voice (but no } \\
\text { eye contact) }\end{array}$ \\
\hline-4 deep sedation & $\begin{array}{l}\text { no response to voice, but movement or eye } \\
\text { opening to physical stimulation }\end{array}$ \\
\hline-5 unarousable & \begin{tabular}{l} 
no response to voice or physical stimulation \\
\hline
\end{tabular} \\
\hline
\end{tabular}


in which the internal lumen is coated with a thin layer of antibacterial substance (e.g. silver ions), which prevents the formation of bacterial biofilm inside the tube $[13,17,20$ 22]. However, the recommendations included in the guidelines are not unequivocal in this respect [15]. It appears that using such tubes is warranted in patients in whom ventilatory support is expected to last longer than 48 hours, as such patients are at high risk of VAP occurrence [23].

The search for new methods or procedures for VAP prevention includes the evaluation of the potential significance of new technological solutions, such as endotracheal tubes with ultrathin or modified (low-volume/low-pressure) cuffs, as well as the maintenance of constant pressure in the tube cuff, the removal of biofilm from the tube lumen with mucus shavers and the routine administration of physiological saline before suctioning of secretions from the trachea [13, 15, 22, 24-26]. It may also be beneficial to employ tubes with cuffs made of polyurethane or other materials (elastane, silicone, latex) instead of PVC, as well as tubes with different cuff shapes, in order to ensure better leak tightness [27-29]. The efficacy of these methods, however, must be confirmed by clinical studies.

\section{Body position}

In order to reduce the risk of gastric aspiration, the patient should be maintained in a semirecumbent position, with the chest and head raised (30-45 ); a flat dorsal position should be avoided [1, 4, 9, 13, 30]. According to the literature, VAP is 3 times more likely to occur in patients lying in a flat dorsal position than in those placed in a semirecumbent position [31].

Some recent reports suggest that placing the patient in a lateral position may be more effective in preventing the aspiration of secretion from the subglottic area and VAP development than placing them in a semirecumbent position $[13,22,32]$. Clinical studies are currently being conducted in order to explain this issue and, perhaps, modify the recommendations. It should, however, be noted that, in the case of cardiac surgery patients, the lateral position could only be considered with regard to patients undergoing modern, minimally invasive procedures that do not involve sternotomy.

\section{Enteral nutrition}

Parenteral nutrition constitutes a significant risk factor of VAP development; therefore, as part of VAP prophylaxis, implementing enteral nutrition is recommended in spite of the risk of gastric content aspiration into the respiratory system [33]. Administering nutrition through a gastric feeding tube prevents intestinal villi atrophy, thus decreasing the risk of bacterial translocation. It should, however, be stressed that although this feeding method is preferred, introducing enteral nutrition too early in intubated patients (within the first two days of ventilation) may increase the risk of VAP in comparison to employing this feeding mode at a later time [34]. It has recently been suggested that feeding the patients with post-pyloric feeding tubes reduces the risk of gastric content aspiration and VAP. Nev- ertheless, none of the clinical studies conducted so far have confirmed this relationship; therefore, the method is not currently recommended [13].

\section{Preventing oropharyngeal colonization}

Colonization of the oropharyngeal cavity by microorganisms is considered to be an independent risk factor of $\operatorname{VAP}[35,36]$. One of the methods of reducing this risk is the local use of antiseptics or antibiotics; it should, however, be emphasized that these measures, while reducing VAP incidence, facilitate patient colonization by multidrug-resistant (MDR) pathogens $[8,37]$. On the other hand, studies conducted among patients, including cardiac surgery patients, demonstrated the positive significance of modulating the bacterial composition of the oral cavity by the local use of chlorhexidine [35, 38]. This measure had a preventive effect with regard to VAP development among the studied patients. An alternative measure consists of preventing oropharyngeal cavity secretions from reaching the lower airway by minimizing sedation and muscle relaxant administration, thus activating the cough reflex and other defense mechanisms of the respiratory system.

Current guidelines concerning VAP prophylaxis highlight the great importance of the patient's oral hygiene [4]. Regular brushing of the teeth, gums and tongue with the use of toothpaste (every 2-4 hours), followed by moistening of the patient's lips, is recommended [39]. The aim of these actions is to remove the proliferated bacterial flora from the oral cavity of the mechanically ventilated patient. These nursing activities may be conducted using commercially available accessories, which can facilitate the performance of this procedure and enhance its efficacy.

Doing this systematically is very efficient with regard to the prevention of bacterial colonization in the patient's oral cavity without the need for the local use of antibiotics or antiseptics, which reduces the selection of MDR bacterial strains. Therefore, the above procedure of regular oral hygiene should be implemented in the patient's daily care plan instead of using local antibiotics or antiseptics.

\section{Pharmacological intervention aimed at neutralizing gastric acid}

In patients hospitalized in intensive care units (ICU) pharmacological prophylaxis of stress-related gastric ulceration is implemented in the form of antacids ( $\mathrm{H} 2$ receptor antagonists or proton-pump inhibitors). Unfortunately, $\mathrm{pH}$ elevation in the stomach creates favorable conditions for bacterial proliferation, eliminates the natural barrier and enables the bacteria to ascend into the upper segments of the gastrointestinal tract and, in the case of gastric content aspiration, also into the bronchial tree [4]. Although such treatment contributes to an increase in VAP incidence, it is still recommended in the current prophylaxis guidelines for this disorder [2, 13, 40]. According to some authors, using sucralfate instead of $\mathrm{H} 2$ receptor antagonists may reduce VAP incidence in mechanically ventilated patients [9]. 


\section{Other options of VAP prophylaxis}

Using the aforementioned procedures and guidelines reduces the risk of VAP, but does not eliminate it completely. Therefore, the search for additional methods of minimizing VAP incidence in patients with ventilation support continues $[13,15,22]$.

Some authors claim that the functioning of the mechanisms of mucociliary clearance and airway secretion clearance may be improved by physical therapy consisting of rotating the patient mechanically by $40^{\circ}$ instead of the regular rotation performed every 2 hours [13]. A meta-analysis of 10 clinical studies indicated that, although this measure reduces VAP incidence, it does not reduce the duration of mechanical ventilation or ICU stay, does not decrease patient mortality, and cannot currently be recommended [41]. Furthermore, it is associated with a risk of complications, such as unplanned extubation or cardiac dysrhythmias. The procedure may also be impossible to apply to patients after cardiac surgery procedures involving sternotomy.

A meta-analysis of prospective controlled studies pertaining to the use of probiotics in VAP prophylaxis indicates that they may be useful in reducing the incidence of this disease [42]. This may be related to the immunomodulatory properties of these agents and the fact that they inhibit the development of pathogenic bacterial flora in the oropharyngeal cavity and the stomach.

\section{Hand hygiene of healthcare staff}

Adhering to the protocols concerning hand hygiene of healthcare professionals is the simplest, and, at the same time, most efficacious and least expensive method of preventing nosocomial infections $[9,17]$. This association was already noted in 1847 by Semmelweis, who ordered the staff of his hospital to regularly disinfect their hands, which reduced the mortality rate among postpartum mothers from $10 \%$ to $1 \%$, proving that the hands of the medical personnel play a fundamental role in the transmission of nosocomial infections. Adherence to hand hygiene protocols by staff attending an intubated patient is crucial in VAP prophylaxis [6].

Hands of medical professionals may be colonized not only by their own physiological flora, but also by pathogens residing in the hospital environment, often equipped with genes of resistance to various antibiotic groups. If the medical staff fails to adhere to hand hygiene protocols, these microorganisms are then transferred to patients, in whom they may cause life-threatening infections. The only efficient method of pathogen removal is to thoroughly wash the hands, dry them, and disinfect them. In clinical practice, disinfection of hands without prior washing them is permitted (or, lately, even recommended) if they are visibly clean. An exception to this rule occurs if the patient is infected or colonized by Clostridium difficile. This bacterium produces spores that are unaffected by alcohol-based hand disinfectants; in the case of contact with a patient infected with this pathogen, washing of the hands is required in order to mechanically remove the spores.
Despite being considered the simplest and most important method in the prevention of nosocomial infections (including VAP), handwashing and hand disinfection protocols are not always adhered to by hospital staff. Studies conducted in the 1990s in American hospitals indicated that only $14-59 \%$ of physicians and nurses comply with the procedure [43]. In spite of the passage of time, these data still remain unsatisfactory - compliance with hand hygiene protocols among healthcare professionals on average does not exceed 50\% [44]. Many reports emphasize that these numbers are lower with regard to physicians in comparison to nursing personnel. The most important element of motivating hospital staff to properly wash and/or disinfect their hands should be the awareness that this practice prevents the transmission of nosocomial infections, reduces treatment costs, and, most importantly, saves patients from suffering or death.

Besides being required to maintain proper hand hygiene, medical professionals are also obliged to use protective clothing, such as gloves, aprons, and masks. Using gloves does not obviate the obligation to wash and/ or disinfect one's hands after each use. Gloves should be changed not only before approaching a new patient, but also in between different nursing procedures performed on the same patient. Protective aprons should also be changed regularly, because during patients' care they become contaminated with microorganisms. In order to prevent the transmission of pathogens from one patient to another, protective clothing should be changed daily, or even more frequently if necessary.

\section{The role of nursing staff in VAP prophylaxis - procedural protocols}

Bronchial clearance is an important element of nursing care provided to intubated patients or patients with tracheotomy tubes, which also reduces the risk of VAP. It should be performed as often as required. The process begins with informing the patient about the necessity of performing this procedure, regardless of the level of the patient's awareness. In order to facilitate the evacuation of secretions from the bronchial tree, the suctioning procedure should be preceded by the administration of mucolytic inhalation, followed by pulmonary alveoli expansion using the ventilator.

Tables IV and V present the basic rules and procedural protocols with regard to bronchial clearance, while Tables VI-VIII present the rules concerning the proper use of equipment (ventilator and oxygen dispenser) in order to minimize VAP risk in mechanically ventilated patients. 
Table IV. Basic protocol for removal of secretions from the bronchial tree of a ventilated patient by suctioning

1. The size of the suctioning catheter should be adjusted to the size of the intubation/tracheostomy tube to prevent lumen occlusion.

2. The kit for the suctioning of secretions is intended for one patient only; it consists of a single-use bag and a drain connected to a sterile catheter

3. After the completion of suctioning, the drain should be rinsed with sterile distilled water, so that the whole volume of the aspirated secretion would remain in a closed bag system.

4. When suctioning secretions from the respiratory tract of the patient, additional protective clothing should be worn in order to prevent contamination by biological material sprayed in the air.

5. If non-sterile gloves are used for suctioning, the catheter should be held in a manner ensuring that the part of the catheter which will be inserted into the tube does not come into contact with the hand or the patient's environment.

6. Each aspiration should be performed using a new sterile catheter.

7. Aspiration should not last more than 10 seconds, due to the increased risk of hypoxia.

8. After placing the catheter in the intubation/tracheostomy tube, it should be removed upwards with a rotational movement, while suctioning the secretion.

9. It is a mistake to insert or remove the catheter whilst it is placed in the tube.

Table VI. Procedure for handling the ventilator after its use

1. A single-use respiratory circuit should be placed in a medical waste bag, in accordance with the protocol for medical waste disposal.

2. Using multiple-use circuits is not recommended.

3. Multiple-use filters should be washed with water and detergent, making sure that no water gets inside. Filters should only be sterilized in autoclaves. Depending on the instructions of the manufacturer, 20-100 sterilization cycles can be performed in a period not exceeding one year.

4. Multiple-use exhalation valves should be washed with water and detergent, disinfected, and sterilized in an autoclave.

5. Flow sensors should be washed with great care. Manufacturers of most equipment permit all methods of sterilization; however sterilization methods should not be used interchangeably, as it results in faster wearing out of equipment. The preferred method for sterilizing flow sensors is the use of ethylene oxide.

6. Housings of ventilators, as well as screens and work panels, should be disinfected with alcohol-based disinfectants in accordance with the manufacturer's guidelines.

7. Filters of the ventilator's cooling system should be disassembled and washed with water and detergent.

8. If water- and heat-resistant surfaces become very dirty, it is recommended to wash them with a stream of pressurized steam.

9. A cleaned, disinfected and sterilized ventilator should be assembled immediately prior to connecting it to the patient. After mounting a new respiratory circuit, the technical condition of the equipment should be checked.

10.Ventilators which are not equipped with multiple-use inhalation filters should be mounted with single-use filters which should be exchanged after 48 hours of operation.

11. Respiratory filters with heat and moisture exchangers should be used; they should be exchanged after 24 hours. Water-based thermal moisteners should not be used.

12. It is recommended to exchange tubes if they are visibly soiled.
Table V. Procedure for removal of secretions from the respiratory tract of a ventilated patient by suctioning

1. Open the packaging of the catheter without removing it.

2. Connect the catheter to the suctioning device.

3. Disconnect the patient from the ventilator.

4. Close the lumen of the catheter with one hand and remove the packaging with the other.

5. Introduce the catheter into the tube.

6. Open the catheter's lumen and remove it upwards with a rotational movement, while suctioning the secretion.

7. Connect the patient to the ventilator and monitor the respiratory parameters.

8. Place the catheter in a medical waste bag in accordance with the protocol for medical waste disposal.

9. Rinse the suction drain with distilled water.

10. Tidy up the worksite.

11. Perform hygienic handwashing and disinfection.

Table VII. Procedure for the handling of an oxygen dispenser prior to its use*

1. Wash and disinfect your hands.

2. Prepare the oxygen therapy kit:

- a drain with a face mask or a double-lumen catheter (nasal cannula) for oxygen administration

- a sterile bottle for the moistener

- a flowmeter, disinfected in accordance with the manufacturer's guidelines

- sterile distilled water.

3. Fill the moistener bottle with $100-150 \mathrm{ml}$ of sterile distilled water.

4. Assemble the oxygen administration kit.

5. Connect the prepared flowmeter and the moistener bottle to the oxygen source.

6. Set an appropriate level of oxygen flow, as instructed by the attending physician.

7. Perform hygienic handwashing and disinfection.

${ }^{*}$ Applies to oxygen dispensers with multiple-use moisteners.

Table VIII. Procedure for the handling of an oxygen dispenser after its use*

1. Perform hygienic handwashing and disinfection.

2. Put on single-use non-sterile gloves.

3. Shut down the oxygen flow.

4. Remove the dispenser from the oxygen source.

5. Place the drain, mask, or nasal cannula in a medical waste bag in accordance with the protocol for medical waste disposal.

6. Disconnect the moistener bottle and remove the water.

7. Disinfect, dry and sterilize the bottle in accordance with the manufacturer's guidelines.

8. Disinfect the remaining parts of the oxygen dispenser with an agent recommended by the manufacturer, rinse them, and dry them out.

9. Take the gloves off and place them in the medical waste bag.

10. Perform hygienic handwashing and disinfection.

11. In between uses, keep the dispenser in a clean and dry environment.

12. The bottle for moisturizing oxygen should be exchanged after every patient, and if used for the same patient it should be exchanged at least once a day.

*Applies to oxygen dispensers with multiple-use moisteners. 


\section{Conclusions}

Awareness of hazards associated with nosocomial infections and their consequences, combined with the knowledge about their causes, epidemiology, risk factors and symptoms, forms the foundation for the efficient control and prevention of such infections.

\section{References}

1. American Thoracic Society, Infectious Diseases Society of America. Guidelines for the management of adults with hospital-acquired, ventilator-associated, and healthcare-associated pneumonia. Am J Respir Crit Care Med 2005; 171: 388-416.

2. Institute for Healthcare Improvement. IHI Ventilator bundle. http://www. ihi.org/knowledge/Pages/Changes/ImplementtheVentilatorBundle.aspx.

3. CDC/NHSN Surveillance definition of healthcare-associated infection and criteria for specific types of infections in the acute care setting. http:// www.cdc.gov/nhsn/pdfs/pscmanual/17pscnosinfdef current.pdf.

4. Coffin SE, Klompas M, Classen D, Arias KM, Podgorny K, Anderson DJ, Burstin H, Calfee DP, Dubberke ER, Fraser V, Gerding DN, Griffin FA, Gross P, Kaye KS, Lo E, Marschall J, Mermel LA, Nicolle L, Pegues DA, Perl TM, Saint S, Salgado CD, Weinstein RA, Wise R, Yokoe DS. Society for Healthcare Epidemiology of America/Infectious Diseases Society of America (SHEA/IDSA) Practice Recommendation. Strategies to prevent ventilator-associated pneumonia in acute care hospitals. Infect Control Hosp Epidemiol 2008; 29: S31-S40.

5. Craven D. Preventing ventilator-associated pneumonia in adults. Chest 2006; 130: 251-260.

6. Flanagan ME, Welsh CA, Kiess C, Hoke S, Doebbeling BN; Agency for Healthcare Research and Quality Hospital-Acquired Infections Collaborative. A national collaborative for reducing health care-associated infections: current initiatives, challenges, and opportunities. Am J Infect Control 2011; 39: 685-689.

7. Morris AC, Hay AW, Swann DG, Everingham K, McCulloch C, McNulty J, Brooks O, laurenson IF, Cook B, Walsh TS. Reducing ventilator-associated pneumonia in intensive care: Impact of implementing a care bundle. Crit Care Med 2011; 39: 2218-2224.

8. Seegobin RD, van Hasselt GL. Endotracheal cuff pressure and tracheal mucosal blood flow: endoscopic study of effects of four large volume cuffs. $\mathrm{Br}$ Med J 1984; 288: 965-968.

9. Hunter JD. Ventilator associated pneumonia. Br Med J 2012; 344: e3325.

10. Lacherade JC, De Jonghe B, Guezennec P, Debbat K, Hayon J, Monsel A, Fangio P, Appere de Vecchi C, Ramaut C, Outin H, Bastuji-Garin S. Intermittent subglottic secretion drainage and ventilator-associated pneumonia: a multicenter trial. Am J Respir Crit Care Med 2010; 182: 910-917.

11. Kollef MH, Skubas NJ, Sundt TM. A randomized clinical trial of continuous aspiration of subglottic secretions in cardiac surgery patients. Chest 1999; 116: 1339-1346

12. Muscedere J, Rewa O, McKechnie K, Jiang X, Laporta D, Heyland DK. Subglottic secretion drainage for the prevention of ventilator-associated pneumonia: a systematic review and meta-analysis. Crit Care Med 2011; 39: 1985-1991.

13. Coppadoro A, Bittner E, Berra L. Novel preventive strategies for ventilatorassociated pneumonia. Crit Care 2012; 16: 210.

14. Griffiths J, Barber VS, Morgan L, Young JD. Systematic review and metaanalysis of studies of the timing of tracheostomy in adult patients undergoing artificial ventilation. BMJ 2005, 330: 1243.

15. Lorente L, Blot S, Rello J. New issues and controversies in the prevention of ventilator-associated pneumonia. Am J Respir Crit Care Med 2010; 182: 870-876.

16. Terragni PP, Antonelli M, Fumagalli R, Faggiano C, Berardino M, Pallavicini FB, Miletto A, Mangione S, Sinardi AU, Pastorelli M, Vivaldi N, Pasetto A, Della Rocca G, Urbino R, Filippini C, Pagano E, Evangelista A, Ciccone G, Mascia L, Ranieri VM. Early vs late tracheotomy for prevention of pneumonia in mechanically ventilated adult ICU patients: a randomized controlled trial. JAMA 2010; 303: 1483-1489.

17. Beth A. Ventilator-associated pneumonia. Risk factors and prevention. Crit Care Nurse 2007; 27: 33-39.

18. Szreter T. Odrespiratorowe zapalenie płuc - profilaktyka i leczenie. Zakażenia 2009; 3: 74-79.

19. Restrepo RD, Walsh BK: Humidification during invasive and noninvasive mechanical ventilation: 2012. Respir Care 2012; 57: 782-788
20. Raad II, Mohamed JA, Reitzel RA, Jiang Y, Dvorak TL, Ghannoum MA, Hachem RY, Chaftari AM. The prevention of biofilm colonization by multidrug-resistant pathogens that cause ventilator-associated pneumonia with antimicrobial-coated endotracheal tubes. Biomaterials 2011; 32: 2689-2694.

21. Kollef MH, Afessa B, Anzueto A, Veremakis C, Kerr KM, Margolis BD, Craven DE, Roberts PR, Arroliga AC, Hubmayr RD, Restrepo MI, Auger WR, Schinner R; NASCENT Investigation Group. Silver-coated endotracheal tubes and incidence of ventilator-associated pneumonia: the NASCENT randomized trial. JAMA 2008; 300: 805-813.

22. O'Grady NP, Murray PR, Ames N. Preventing ventilator-associated pneumonia. Does the evidence support the practice? JAMA 2012; 307: 2534-2539.

23. Shorr AF, Zilberberg MD, Kollef M. Cost-effectiveness analysis of a silvercoated endotracheal tube to reduce the incidence of ventilator-associated pneumonia. Infect Control Hosp Epidemiol 2009; 30: 759-763.

24. Berra L, Coppadoro A, Bittner EA, Kolobow T, Laquerriere P, Pohlmann JR, Bramati S, Moss J, Pesenti A. A clinical assessment of the Mucus Shaver: a device to keep the endotracheal tube free from secretions. Crit Care Med 2012; 40: 119-124.

25. Fernandez JF, Levine SM, Restrepo MI.Technologic advances in endotracheal tubes for prevention of ventilator-associated pneumonia. 2012; 142: 231-238.

26. Nseir S, Zerimech F, Fournier C, Lubret R, Ramon P, Durocher A, Balduyck $M$. Continuous control of tracheal cuff pressure and microaspiration of gastric contents in critically ill patients. Am J Respir Crit Care Med 2011; 184 1041-1047.

27. Miller MA, Arndt JL, Konkle MA, Chenoweth CE, Iwashyna TJ, Flaherty KR, Hyzy RC. A polyurethane cuffed endotracheal tube is associated with decreased rates of ventilator-associated pneumonia. J Crit Care 2011; 26: 280-286.

28. Dave MH, Frotzler A, Spielmann N, Madjdpour C, Weiss M. Effect of tracheal tube cuff shape on fluid leakage across the cuff: an in vitro study. $\mathrm{Br}$ J $\mathrm{An}$ aesth 2010; 105: 538-543.

29. Kolobow T, Cressoni M, Epp M, Corti I, Cadringher P, Zanella A. Comparison of a novel lycra endotracheal tube cuff to standard polyvinyl chloride cuff and polyurethane cuff for fluid leak prevention. Respir Care 2011; 56 1095-1099.

30. Niel-Weise B S, Gastmeier P, Kola A, Vonberg RP, Wille JC, van den Broek PJ; Bed Head Elevation Study Group. An evidence-based recommendation on bed head elevation for mechanically ventilated patients. Critical Care 2011; 15: R111.

31. Drakulovic MB, Torres A, Bauer TT, Nicolas JM, Nogue S, Ferrer M. Supine body position as a risk factor for nosocomial pneumonia in mechanically ventilated patients: a randomised trial. Lancet 1999; 354: 1851-1858.

32. Mauri T, Berra L, Kumwilaisak K, Pivi S, Ufberg JW, Kueppers F, Pesenti A, Bigatello LM. Lateral-horizontal patient position and horizontal orientation of the endotracheal tube to prevent aspiration in adult surgical intensive care unit patients: a feasibility study. Respir Care 2010; 55: 294-302.

33. Chen YC. Critical analysis of the factors associated with enteral feeding in preventing VAP: a systematic review. J Chin Med Assoc 2009; 72 : 171-178.

34. Artinian V, Krayem H, DiGiovine B. Effects of early enteral feeding on the outcome of critically ill mechanically ventilated medical patients. Chest 2006; 129: 960-967.

35. Segers P, de Mol BA. Prevention of ventilator-associated pneumonia after cardiac surgery: prepare and defend! Intensive Care Med 2009; 35: 1497-1499.

36. Torres A, el-Ebiary M, Gonzalez J, Ferrer M, Puig de la Bellacasa J, Gené A, Martos A, Rodriguez-Roisin R. Gastric and pharyngeal flora in nosocomial pneumonia acquired during mechanical ventilation. Am Rev Respir Dis 1993; 148: 352-357.

37. Roeleveld PP, Guit D, Kuijper EJ, Hazekamp MG, de Wilde RB, de Jonge E. Ventilator-associated pneumonia in children after cardiac surgery. Intensive Care Med 2011; 37: 1656-1663.

38. Koeman M, van der Ven AJ, Hak E, Joore HC, Kaasjager K, de Smet AG, Ramsay G, Dormans TP, Aarts LP, de Bel EE. Oral decontamination with chlorhexidine reduces the incidence of ventilator-associated pneumonia. Am J Respir Crit Care Med 2006; 173: 1348-1355.

39. Cutler CJ, Davis N. Improving oral care in patients receiving mechanical ventilation. Am J Crit Care 2005; 14: 389-394.

40. Herzig SJ, Howell MD, Ngo LH, Marcantonio ER. Acid-suppressive medication use and the risk for hospital-acquired pneumonia. JAMA 2009; 301 2120-2128.

41. Delaney A, Gray H, Laupland KB, Zuege DJ. Kinetic bed therapy to prevent nosocomial pneumonia in mechanically ventilated patients: a systematic review and meta-analysis. Crit Care 2006; 10 (3): R70. 
42. Siempos II, Ntaidou TK, Falagas ME: Impact of the administration of probiotics on the incidence of ventilator-associated pneumonia: a metaanalysis of randomized controlled trials. Crit Care Med 2010; 38: 954-962.

43. Kurlenda J. Monitorowanie zakażeń i analiza epidemiologiczna w oddziale intensywnej terapii. Urban \& Partner, Wrocław 2000; 47-51.

44. Institute for Healthcare Improvement: How-to guide: Improving hand hygiene. A guide for improving practices among health care workers. www.ihi.org. 